IN 1897, Mr. E. W. Swanton became curator of the Museum and still holds that office. The founder died in 1913; no provision had been made for its future, and it was taken over by a committee with Sir Archibald Geikie as chairman. From that time to the present, the necessary funds to allow the work to continue have been subscribed year by year chiefly by local residents. As its activities steadily increased, it became more and more desirable that the Museum should be moved to a central position. In 1925 the committee purchased an old house with beautiful grounds in Haslemere High Street; new galleries for the adequate display of the space-for-time schedules were added and the collections removed there in 1926. Afterwards a new gallery was added to contain a valuable gift of British birds. Through grants from the Carnegie United Kingdom Trust, the work has been extended to include a regional and ecological survey of the district. The value of the Museum as a teaching centre is widely known. Every autumn mycology students from the University of Oxford make it their headquarters. A course in field biology held at Whitsun attracted students from a wide area.

\section{Hittites in Northern Syria}

ONCE more Sir Leonard Woolley's archæological investigations in the East have produced unanticipated results. In his dispatch from Atchana in Northern Syria (The Times, June 13), which covers the work of his expedition during the first half of the current season, he records that two hundred inscribed tablets have been found, which reveal for the first time the existence of a strongly established and highly organized Hittite power in Northerm Syria at about 1600 B.c., at least two centuries before the great expansion of the Hittite Empire, centring on Hattusas (Boghaz Keui) beyond the Taurus, in what is now Anatolia, with which scholars were previously familiar from excavation and inscribed records. These archives are part of the official documents removed from the Hittite palace, of which a preliminary examination was made at the close of last year's excavations, and now shown to have been destroyed by fire, presumably accidental, as the contents of the building had been removed. The most striking feature of the building, in the account given by Sir Leonard, is the skilled arrangement and the elaborate character of the accommodation. The ruins, still standing to more than a man's height, cover more than 22,000 square feet. Access to the building is from an open courtyard and through a great entry into an entrance hall, from which doorways right and left give admission to the business and residential quarters of the palace respectively. These were virtually separate buildings without intercommunication, and the difference in their character and arrangement indicate their entirely different purposes. In the residential quarter, intended, Sir Leonard thinks, for important members of the palace personnel-the royal family being accommodated above, and the domestic staff, equipment and stores being housed in the courtyard in front of the entrythe accommodation consisted of suites, each of which contained a good-sized bathroom and lavatory. The whole arrangement and content of the palace is, as Sir Leonard remarks, eloquent of a strong and stable government ; while the pottery, ivory and gold work bear witness to relations with Cyprus, Crete, Phenicia and the Greek mainland, as well as with Egypt and Mesopotamia.

\section{The Unity Schools}

THE fifteenth Unity School was held at Jordans Hostel in Bucks, on May 20-23. The general subject was the need and the relation of philosophy to the social sciences, and an introductory address on that topic was given by Prof. Morris Ginsberg, on the evening of May 20. On May 21, Mr. F. S. Marvin introduced the central subject of "What we mean by Social Justice", and the liveliness of the discussion showed clearly how deeply the current thinking on these questions goes, and how much it needs clarification and, so far as possible, harmonization. Dr. C. H. Desch introduced the question of the comparison of our approach to truth in physical and social science, and Prof. Herbert Dingle gave a parallel statement. In particular the question was raised, and viewed from several angles, of whether it is possible in social science properly to speak of a scientific experiment. On May 22, Prof. J. H. Muirhead gave a carefully prepared and moving discourse on the place of the State in relation to right and justice, with the title, "State Law and Individual Morality". The programme, as originally drawn up, was concluded on the Sunday evening by a historical review by Dr. A. J. Carlyle of the various larger subjects which had occurred in the earlier debates-justice, law, sovereignty and the freedom and equality of men-mainly as they are treated in the codes and writings of Greeks, Roman jurists and medieval thinkers. In view of the great success and obvious usefulness of such gatherings, the possibility of extending them to a larger number of people, more frequent occasions and a still wider expanse of subjects is being considered. Further information on the Unity Schools can be obtained from Mr. F. S. Marvin, Pantiles, Coneydale, Welwyn Garden City, Herts.

\section{Correct Street Lighting}

THE General Electric Co. Ltd. has installed in its street-lighting showroomsat Magnet House, Kingsway, London, W.C.2, a model demonstrating many of the problems that arise in street lighting and how they have been effectively solved by the methods recom mended in the final report on street lighting issued by the Ministry of Transport. The model measures $5 \mathrm{ft}$. long by $2 \mathrm{ft}$. wide, the lighting columns and roads being to a scale of 1 in 380 . Running the whole length of the modes is a main arterial road lighted by columns which in practice would provide a mounting height to light source of $25 \mathrm{ft}$. for a main road (Group $A$ ). The thoroughfare is lighted by a staggered arrangement of units not more than $150 \mathrm{ft}$. apart. In every third position an auxiliary unit is centrally suspended, so that there can be adequate lighting down and across what would otherwise be a dark central section of the road. After a roundabout, 
there is a dual carriage way and it is emphasized how necessary it is to treat dual carriage ways as if they were two separate roads. When the dual road bends away in the country from the 'roundabout', the lighting points become closer on the outside of the bend. Cross-road lighting treatment is also shown in several places. Lights here are arranged just beyond the crossing on the left-hand side as the traffic proceeds; then traffic moving at right angles and pedestrians preparing to cross the road become clearly visible. In addition, photographs are shown to illustrate the more important features demonstrated by the model and suggested in the recom. mendations. A fuller description of this model is given in the Osram G.E.C. Bulletin of May 1938.

\section{Short-Circuit Testing Stations}

Aвour ten years ago it was found necessary to build short-circuit testing stations in order to find out the true rating for a large switch or currentbreaker. In order to find out how a switch will break a large electric current at a low voltage or a current at a very high voltage, different methods have to be used and special large and expensive devices are necessary. It is very unsatisfactory to assign nominal ratings based on theoretical design considerations and experience gained by similar apparatus. The International Electrotechnical Commission has now published a specification for the short-circuit testing of circuitbreakers, and manufacturers have to issue a certificate with the apparatus stating that it has passed the required proving tests. Eight years ago Messrs. Reyrolle and Co. built the first short-circuit testing station at Hebburn-on-Tyne and since then, two more have been erected in Great Britain and others are being constructed or are under contemplation. According to the Electrical Power Engineer of December last, the certification of switches is not exclusively confined to those manufacturers who own testing stations in whole or in part. The facilities of all the British proving stations are open to other manufacturers for making tests. This entails a definite assurance from the testing stations of privacy in testing and secrecy of results of experiments making so much noise and requiring so large a space. All work is carried out on apparatus under a reference number, the manufacturer's name being omitted and also the designation of the apparatus. During testing all entrances to the station are locked. A separate office is provided for the use of customers wishing to discuss reports. Sometimes cinematograph films of the tests are shown at these offices.

\section{Paris Academy of Sciences}

The "Annuaire" of the Paris Academy of Sciences has for some years past included a biographical index of past and present members and correspondants of the Academy. In this year's volume (Paris : Gauthier Villars, 1938), this index is considerably enlarged; notes have been added indicating the subject or subjects in which each individual was particularly interested, and the list of names has been augmented by including the members of the older body, the
Royal Academy of Sciences (1666-1795). A paper read by Prof. Alfred Lacroix, one of the permanent secretaries of the Academy, at the meeting held on January 4 last (C.R., 206, 23), explains the changes that have been made and describes briefly the various previous attempts to provide a complete statement of past and present members of the Academy. The archives of the Academy now have a separate file for each individual who has been connected with it, and every effort is being made, by searching national, parish and other records, to ensure that biographical details are correct. Further, by dint of most painstaking research, the documents relating to the proceedings of every meeting of the Academy, apart from biographical material, have been classified and they are now also arranged in files, one to each meeting from that of " 6 nivôse an IV" (December 27, 1795). As regards meetings of the Royal Academy of Sciences, there are in the archives 109 large folio volumes of Proces verbaux prepared by the five successive permanent secretaries, J.-B. du Hamel, Fontenelle, Dortous de Mairan, Grandjean de Fouchy and Condorcet, which go back to the first meeting on December 22, 1666. The total number of men of science who have belonged to the Academy since 1666 is 2,071 (members, 992; correspondants, 1,079); it possesses nearly sixteen hundred autographs and about the same number of portraits.

\section{Curtis's Botanical Magazine}

A COMPLETE volume of this beautifully illustrated botanical periodical has recently been published in one cover (Curtis's Botanical Magazine, 147. London : Bermard Quaritch, Ltd. 63s, net). This is to fill a gap in the series created by the non-appearance of a volume in 1921. At the end of 1920, publication of the Magazine ceased, and it seemed possible that the copyright would pass to an owner in the United States; but in 1921, the Royal Horticultural Society was presented with the copyright through the generosity of subscribers. The gap thus created in the series has now been filled through the generosity of Mr. Reginald Cory, and the volume is dedicated in accordance with his wish to Sir Isaac Bayley Balfour, Sir David Prain and Sir Frederick Moore in recognition of their services to botany and horticulture. Fifty-seven plants are described and beautifully illustrated, including eleven species of Rhododendron, fifteen of Primula and four of Gentiana. Plants from all parts of the world are described in the Magazine; but in this volumeChinese plants take pride of place-thirty-eight species; five South African species are described and the rest come from countries so far apart as Peru, Siberia, Japan and Tibet. The method familiar to all readers of this periodical is adopted. The history of each species, so far as it is known, is briefly given, and this is followed by a detailed description of morphology (especially floral) and distribution. The beautifully coloured illustrations of each plant described are, of course, the main feature of the volume. The authoritative nature of the text cannot be questioned. Here one notices such familiar contributors as $O$. Stapf (seventeen species alone and ten in collaboration either with 